\title{
RUI TORRES, PRECURSOR DE HEBERTO HELDER E RAUL BRANDÃO: REIMAGINAÇÃO NA POÉTICA DIGITAL
}

\section{RUI TORRES PRECURSOR OF HERBERTO HELDER AND RAUL BRANDÃO: REIMAGINATION IN DIGITAL POETICS}

\author{
Keilla Conceição Petrin Grande \\ Centro Federal de Educação Tecnológica de Minas Gerais, Varginha, Minas Gerais, Brasil \\ keillacpg@gmail.com \\ Rogério Barbosa da Silva \\ Centro Federal de Educação Tecnológica de Minas Gerais, Belo Horizonte, Minas Gerais, \\ Brasil \\ rogeriobsilva@cefetmg.br
}

Resum0: A literatura digital é uma das vertentes da literatura contemporânea, cujos textos partem de recursos hipermidiáticos e digitais em seu processo de elaboração. As escritas assim caracterizadas tanto apresentam inovações no campo estético, quanto preservam, reconfiguram e renovam modalidades do fazer literário inscritas na tradição. Nessa perspectiva, situa-se o texto Húmus - poema contínuo, do escritor português Rui Torres, que, além das várias mídias - som, imagem, texto - de que dispõe na produção do poema, estabelece diálogo com duas obras anteriores: o romance Húmus, de Raul Brandão, publicado em 1917, e o poema homônimo de Herberto Helder, de 1967. Nossa proposta, então é, a partir do trabalho de Torres, pensar como os meios digitais afetam a relação com o texto literário impresso, seja no ato da criação ou no da leitura, e discutir como se operam a retomada e o diálogo com as obras do passado. Nossa análise se fundamenta nos Estudos da Intermedialidade, de Irina Rajewsky, bem como no conceito de remediação, de Bolter \& Grusin. Tomamos também a ideia de escrita palimpséstica, tal como a formula G. Genette, e a reflexão de Borges sobre a releitura da tradição, entendendo que, ao se apropriar de um texto, o poeta promove um desvio em relação ao texto precursor.

Palavras-chave: Poema hipermídia; Intermidialidade; Palimpsesto; Húmus - poema contínuo

Abstract: Digital literature is one of the fields of contemporary literature, whose texts have, in their elaboration process, digital resources, and hypermedia. The writings characterized as such present innovations in the aesthetic field, as well as preserve, reconfigure and renew modalities of literary making inscribed in tradition. In this perspective, the text Húmus - continuous poem, by Portuguese writer Rui Torres, which, in addition to the various media available in the production of the poem, establishes a dialogue with two previous works: the novel Húmus, by Raul Brandão, published in 1917, and the homonymous poem by Herberto Helder, published in 1967. Then, having in mind Torres' work as our starting point, we aim to reflect on how digital media affect the relationship with printed literary text, whether in the act of creation or reading. We would also like to discuss how to operate the dialogue with the works of the past mentioned above. Our analysis is supported by the studies of intermediality carried out by Irina

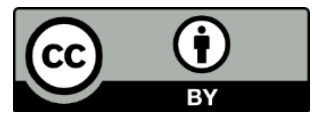


Rajewsky and the concept of remediation developed by Bolter \& Grusin. Besides, we embrace the idea of palimpsest writing, as formulated by G. Genette, and take into consideration Borges' reflection on the rereading of tradition, understanding that, when appropriating a text, the poet promotes a deviation to the precursor text.

Keywordls: Hypermedia poem; Intermediality; Palimpsest; Humus - continuous poem

Ao percorrermos a história da literatura e das artes em geral, observamos que os seus criadores sempre lançaram mão dos recursos tecnológicos disponíveis na produção de seus artefatos, uma vez que é próprio do homem reelaborar suas experiências humanas em seu tempo e comunicar essas experiências através dos meios de que dispõe. Se hoje se observa a tendência de criar com o computador, essa atitude significa menos uma posição tecnofílica que um propósito de apropriação crítica das novas conexões sígnicas impostas pela máquina. $\mathrm{Na}$ história da escrita, por exemplo, sabemos o quanto a invenção da imprensa impactou a produção artesanal dos manuscritos, ou como a máquina de escrever redefiniu as práticas de escrita, alterando o modo de escrever, como discute M. Heidegger em Sobre a mão e a máquina de escrever (1942-1943) (2019). Na perspectiva deste filósofo, a máquina arranca a escrita do âmbito essencial e humano da mão. Nostalgicamente, entende que a palavra no texto datilografado é degradada a um meio de comunicação, uma mera transcrição (HEIDEGGER, 2019, p. 276-277). O pensamento exposto serve para mostrar que uma tecnologia pode alterar severamente as bases que sustentaram certas práticas de escrita, ainda que muito delas permaneça na sociedade. Por exemplo, é possível encontrar autores que escrevam com lápis ou com uma antiga máquina de escrever, antes de transpor o texto para a memória de um computador e tratá-lo com os softwares de edição. Por esta ótica, não é difícil entendermos que a escrita computacional interfere fortemente na produção estética dos textos, além de incorporar-se aos processos ficcionais e metatextuais ou de expor essas produções criativas a novas abordagens e métodos críticos. Feitas essas considerações, o ponto central deste artigo consiste em analisar os processos de recriação de obras impressas no domínio digital, tendo por base as reimaginações de Rui Torres e Herberto Helder sobre a obra de Raul Brandão.

As produções digitais que têm por objeto a recriação de trabalhos impressos normalmente acrescentam a essas obras uma relação com outras linguagens, como, por exemplo, os códigos de programação, e promovem uma integração ao verbal dos recursos de mídias audiovisuais, animação de palavras, entre outras. Portanto, é importante verificarmos a maneira como essas recriações se apropriam dos recursos dessas linguagens, evidenciando a potencialidade dos novos meios; ou por ainda exporem como se opera a relação entre as várias mídias usadas no processo de produção. Nesses casos, os Estudos da Intermidialidade se tornam pertinentes à análise de textos literários, ou melhor, dessas novas textualidades em que se operam a convergência de mídias. Além disso, torna-se interessante avaliar como esses processos de hibridação renovam potências antes implícitas no verbal, mas não exploradas, como vislumbra a poesia concreta com sua ideia de verbivocovisualidade.

Nesse contexto, pode-se também discutir os processos de convergências entre meios, de onde derivam conceitos como o de "remediação", cunhado em 1996 por Sandra Beaudin e proposto por Bolter e Gruzin (2000), em Remediation: understanding New Media. Após historicizarem o conceito, os autores consideram o desenvolvimento e a interseção de mídias como: fotografia digital, jogos computacionais, filmes, arte digital, etc. e as novas relações estabelecidas na Web, na realidade virtual, na computação ubíqua, entre outras. É nesse 
contexto que mídias novas e velhas, dos meios eletrônicos e impressos/analógicos, buscam reafirmar sua existência e validade, refletindo a necessidade de se pensar conceitualmente as obras que gravitam de um meio a outro. Noutro livro, Jay David Bolter discute o campo da materialização da escrita e entende que, desde a antiguidade, há impacto na mudança cultural da oralidade para a escrita, com o surgimento dos livros de pedras, madeira ou pergaminho; e depois, do manuscrito para o impresso tipográfico, tal como agora da tipografia impressa para o digital, e tudo isso implica processos de Remediação. Segundo o autor: "Podemos chamar cada uma dessas mudanças de 'remediação' no sentido que um meio mais novo toma o lugar de um mais velho, borrando e reorganizando as características de escrita nesse velho meio e reformulando seu espaço cultural ${ }^{1}$." (BOLTER, 2001, p. 23). Em outras palavras, o meio muda, mudam também as condições de existência e recepção do conteúdo na relação entre o novo e velho. É o próprio "espaço de escrita" que se altera.

Nesse sentido, as poéticas digitais e a hipermídia afetaram sobremaneira o campo do que entendemos por literatura, na medida em que os processos de hibridação entre palavra e imagem, isto é, entre linguagens, intensificam-se de forma dinâmica e até naturalizada no meio digital. Assim, a literatura, materializada pela palavra, é fortemente associada à cultura escrita e impressa, especialmente a partir da prensa guttenberguiana, em detrimento da cultura oral. Dessa maneira, os textos são geralmente concebidos para o meio impresso e, mesmo que imagem e texto convivam na página, as mídias permitiram friccionar os processos de composição de sua textualidade nas plataformas eletrônica e impressa. Edgar Kirchof, no artigo Como ler os textos literários na era da cultura digital, mostra que o ciberespaço, no qual estariam situados todos os textos digitais,

propiciou grande liberdade para a produção e a divulgação de textos literários, pois, além de não acarretar custos significativos na maior parte dos casos, não há qualquer regulação ou controle editorial para se publicar uma obra em blogs ou em sites da internet. (KIRCHOF, 2016, p. 204).

Observa-se, por esse viés, que a liberdade de produzir novas formas textuais escapa aos processos de legitimação constituídos não só pelas cadeias de produção do livro, como também pela acadêmica, o que afeta a percepção do que seja literatura ou poesia, para ficar no caso que nos interessa. Por outro lado, essas novas textualidades impõem aos leitores outras demandas de letramento para que possam ler e fruir as obras disponíveis no ciberespaço, como discute Kirchof. Desse modo, a literatura nos interpela, obrigando-nos à reformulação das teorias do texto e da leitura e, em certa medida, de seu próprio campo de conhecimento.

Nesse contexto está inscrito Húmus - poema contínuo (2008), de Rui Torres. Enquanto jogo literário e diálogo com a tradição, observamos que Torres parte de duas outras obras da literatura lusitana: Húmus (1917), de Raul Brandão, e Húmus (1967), de Herberto Helder. A obra digital se apropria dos processos criativos dos textos precedentes, para a qual traz outros procedimentos específicos da programação e da edição audiovisual. É imperativo pensar, então, as reconfigurações que elas ganham na (re)escrita do ciberpoeta e, ainda, como os meios digitais modificam e potencializam de várias formas a escrita literária

Além disso, considerando a dimensão textual e os jogos intertextuais, percebemos o imbricamento estético de processos criativos nas várias camadas de Húmus - poema contínuo, uma vez que o texto hipermidiático é formado por camadas palimpsésticas de escrita, dentro da

1 "We might call each such shift a 'remediation', in the sense that a newer medium takes the place of an older one, borrowing and reorganizing the characteristics of writing in the older medium and reforming its cultural space." 
perspectiva genettiana de uma literatura de segundo grau. Assim o texto de Helder é um palimpsesto escrito da obra de Brandão, num primeiro plano, e a recriação da hipermídia recompõe, em novas configurações, os textos de Brandão e Helder. E é nesse sentido que também se pode afirmar que Rui Torres cria os seus precursores, como propõe Borges no ensaio Kafka y sus precursores (2009).

\section{Processos criativos e hipermidiáticos em Húmus, poema contínuo}

A obra hipermídia Húmus, poema contínuo (2008) apresenta-se como um link de flash app com som, no endereço https://telepoesis.net/humus/humus_index.html e numa versão em CD-ROM (versão melhorada) no livro Herberto Helder Leitor de Raul Brandão, a qual contém um link para versão em inglês na Web. Todas são descritas como programação textual de Rui Torres com som e textos combinatórios animados a partir de Húmus, de Herberto Helder (1967) e Húmus, de Raul Brandão (1917).

Apesar das explícitas referências aos "Húmus" que a precederam, o poema de Torres constitui-se, como as anteriores, em textualidade autônoma. O ciberpoeta realiza um processo de "desmontagem", conforme descreve no livro Herberto Helder, leitor de Raul Brandão, em que os textos de Helder e Brandão são postos em confronto, sendo o critério:

o texto de Helder aparece em posição privilegiada, sendo por isso o texto que aparece em primeiro lugar. Por forma a facilitar a leitura e a consulta, usamos um tipo de letra diferente (serifada e a bold) no texto de Brandão utilizado por Helder. (TORRES, 2010, p. 44).

Percebe-se, portanto, a pinça de Helder sobre o texto de Brandão, seus anacolutos e elipses, operando poeticamente sobre a prosa do segundo autor. Na terceira parte do livro, Torres descreve o processo de recombinação e apresenta a obra Húmus, poema contínuo (CDROM) definindo o texto como "uma investigação criativa na área da ciberliteratura, que tem como objetivo propor novas formas do poema-montagem" (TORRES, 2010, p. 100), para o qual utiliza como ferramenta de programação textual o "Poemário", isto é, uma aplicação programada para Actionscript 3.0 (linguagem de programação para ambientes virtuais), que permite a qualquer utilizador construir textos (poemas, narrativas, cartas, etc), seguindo procedimentos combinatórios. Trata-se de uma ferramenta que potencializa o texto, permitindose a multiplicidade de versões com interações de um leitor, que pode também escolher um processo de geração automática de leituras do texto animado e sonorizado no Flash e no recurso Actionscript na página Web. Outro fator interessante é que a página do "Poemário" arquiva as versões do poema gerado e permite o seu compartilhamento, conforme o desejo de cada leitor: 
Hоме

Figura 1 - Página do Poemário gerada pelos autores

incêndio isto, por rogério barbosa
Pátios de línguas roídas pelo único
esforço da erva: o muro -
a pedra, a ruina, a fome
a porta.
Tudo isto flutua debaixo
de erva, debaixo de palavras
- Suportas
o incêndio dos mortos?
This entry was posted in poemas on September 27.2019 by perl.

cor aquece, por rui_ccmu

um actor aquece o fruto da variaçăo

entristecendo a cor pálida

do rumor

e sofre escombros

propondo o percurso

da renúncia

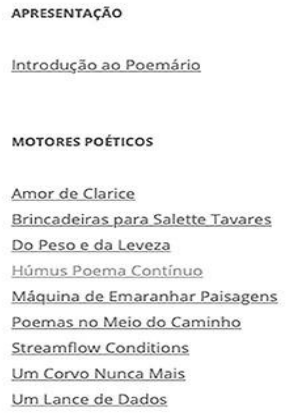

POEMAS DOS LEITORES (CATEGORIAS)

Alletsator

Amor de Clarice

Brincadeiras para Salette Tavares

Do Peso e da Leveza

Húmus Poema Continuo

Maquina de Emaranhar Paisagens

Fonte: http://telepoesis.net/poemario/

A aplicação de programação textual funciona tanto na página da web quanto na execução do aplicativo em CD-ROM, havendo no site outros exemplos de recriações. Mas sua integração em cada projeto permite a instauração de uma forma dinâmica de multiplicação de versões a cada vez que um leitor interage com as produções. Há, no "Poemário", segundo o autor de Húmus, poema contínuo, várias opções de funcionamento do texto-programa: a) animação automática ou interação, em que as palavras alteram-se de modo aleatório e automático ou por decisão do leitor, que seleciona as palavras que vão modificando-se no jogo combinatório; b) edição de listas, em que o leitor acede às listas de palavras programadas e promove a alteração nos planos textuais; c) som, em que, conforme a opção do leitor em ativálo ou não, a sonorização do texto se apresentará num procedimento combinatório alternando entre vozes e texturas sonoras (TORRES, 2010, p. 100). Enfim, as páginas, na Web ou no aplicativo em CD-ROM, informam ao leitor o número de combinações possíveis com a indicação numérica após o símbolo @, posicionado na base da página, à esquerda.

A textura sonora do poema digital não é fixa, mas a cada acesso ao texto, ela se apresenta de forma diferente ao leitor, o que constitui-se uma nova configuração textual, ainda que continue a referenciar as obras de Helder e Brandão (essa liberdade também corresponde ao pensamento de Helder). Eventualmente, pode ocorrer uma performação que não corresponda às estrofes que aparecem na tela quando da interação com o poema digital. No artigo Húmus: colagem; montagem; recombinação, no qual Torres e Ministro realizam uma análise de Húmus poema contínuo, os autores explicitam esse processo sonoro do texto:

\footnotetext{
o som é gerado de modo dinâmico e aleatório, a partir de bancos de dados previamente gravados, compostos por leituras de fragmentos de ambos os textos, a que se juntam texturas sonoras e ambientes musicais variados. A cada nova leitura deste trabalho temos como ponto de partida uma configuração textual completamente distinta da anterior, tanto ao nível verbal quanto em relação à banda sonora que acompanha a navegação. (MINISTRO; TORRES, 2016, p. 167)
}

Um aspecto relevante da produção do poema digital é que as versões das aplicações do motor-textual, que gera a obra, atualizam-se progressivamente, permitindo a incorporação 
de novas funcionalidades, o que também altera o sentido geral da obra. Por exemplo, a ferramenta "Poemário" - descrita como "máquina de sonhar", em referência ao próprio Helder, em sua "máquina de emaranhar paisagens" - orienta o leitor/interator para as suas funcionalidades criativas 1) ler, ouvir, combinar; 2) interagir, transformar, recriar; 3) contribuir, partilhar, conservar. Noutra coluna desta subpágina, o usuário descobre que pode também agir pelos links: @ (enviar), ./ (editar)e ? (ajuda). Em fontes menores, há ainda instruções para a interação digital, como se vê no seguinte print:

Figura 2 - Página de edição do Poemário

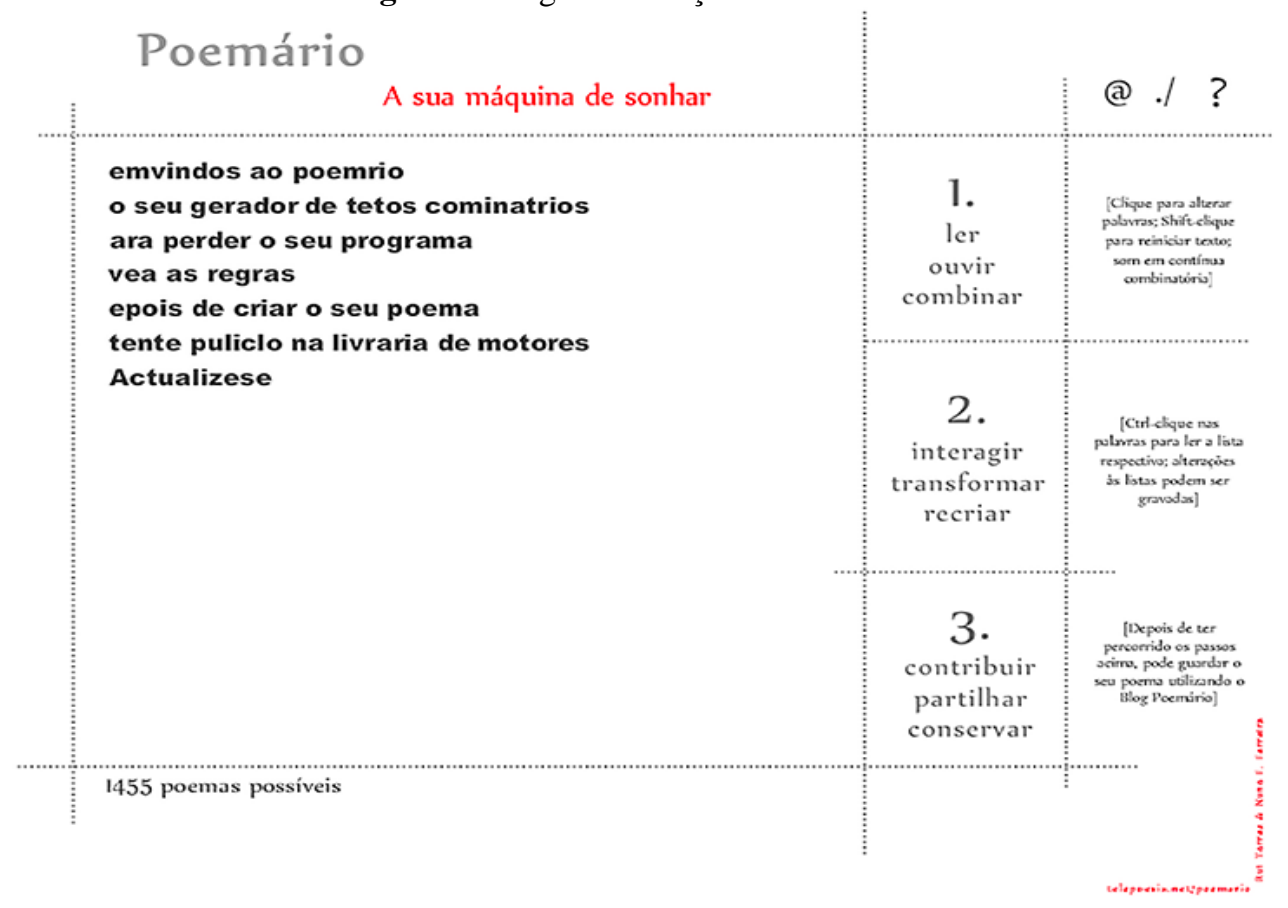

Fonte: http://telepoesis.net/poemario/

Se o leitor clica em "editar", será direcionado para esta outra página, onde poderá "programar" o seu poema, interferindo em palavras ou versos presentes nas listas: 
Figura 3 - Ajuda Programação Poemário

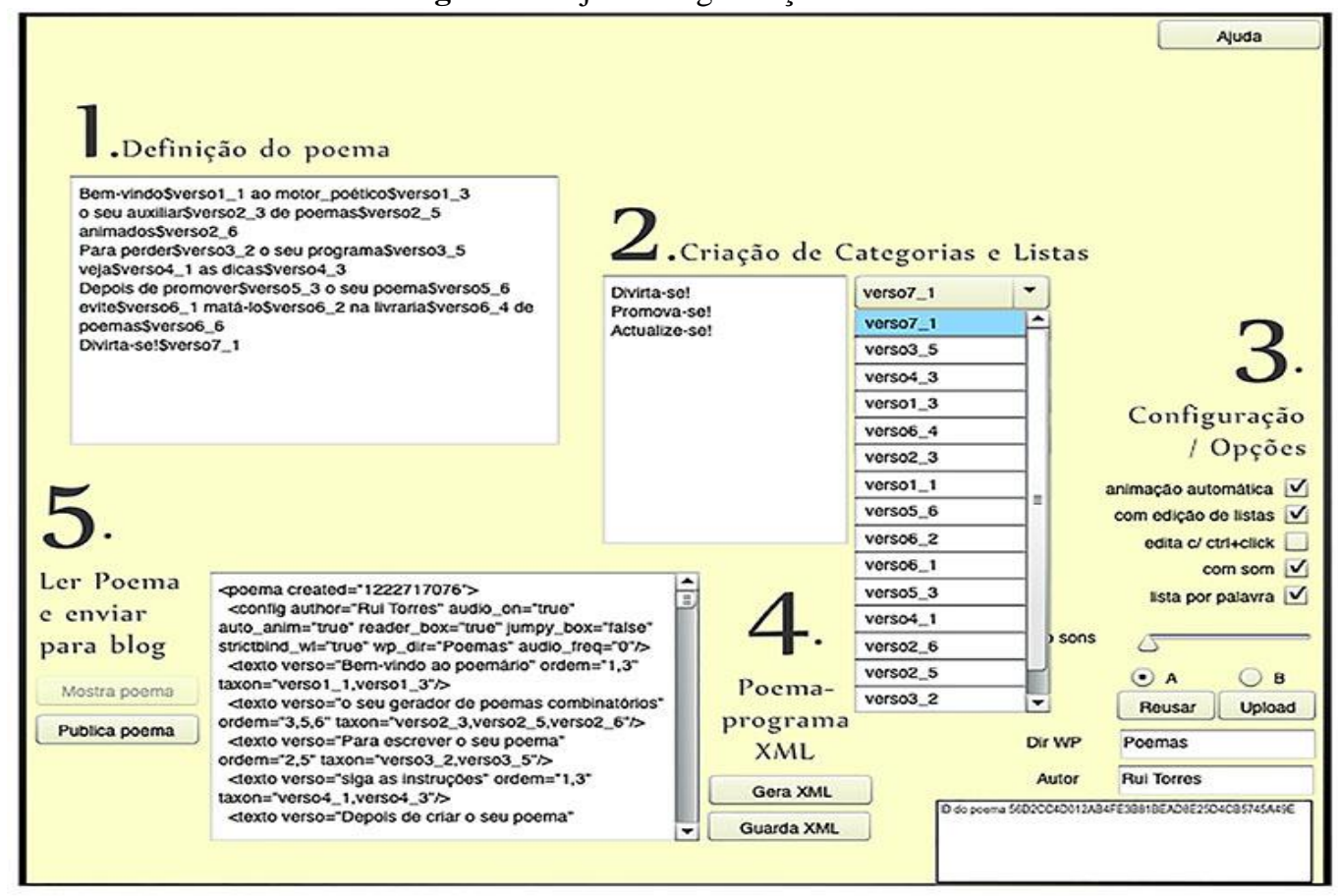

Fonte: http://telepoesis.net/poemario/

Há ainda uma série de pormenores relevantes na programação do texto eletrônico e da própria reconfiguração da obra criativa Húmus nas plataformas digitais. Mas, pelo que descrevemos, acreditamos ser perceptível que a obra hipermidiática de Rui Torres oferece ao leitor não apenas a fruição da leitura, mas também meios para operar criativamente sobre os textos da tradição. A "tradução criativa" e multiplataforma em perspectiva da hipermídia, isto é, que agrega recursos visuais e sonoros ao texto, além de vários níveis de interatividade, permite que leitores com habilidades de leitura menos desenvolvidas aprendam sobre a obra nos seus planos críticos e criativos. Ao operar com o texto, esse leitor ou interator descobre os "algoritmos" (ou potencialidades combinatórias) do texto verbal das obras impressas. Ou se quisermos, redescobre-se a lógica de Herberto Helder sobre o texto de Brandão, expandida a novos horizontes. Disso, trataremos um pouco a seguir.

Considerando os procedimentos textuais apontados acima, vale refletir sobre as discussões da pesquisadora Irina Rajewsky, em seu trabalho Intemidialidade, intertextualidade $e$ "Remediação" - uma perspectiva literária sobre a intermidialidade, em que a autora nos propõe formas de abordagens nos estudos intermídias. Em primeiro lugar, ela mostra-nos os modos como a intermidialidade têm sido explorada, chegando a três concepções: 1) por abordagem sincrônica e diacrônica; 2) como condição de "análise concreta de produtos ou configuração de mídias individuas"; 3) pelo reconhecimento da intermidialidade em determinados processos. A partir dessa disposição e no intuito de "analisar exemplos individuais em relação a sua especificidade", Rajewsky se detém na segunda concepção, ou seja, no estudo de produtos/obras de caráter intermidial, a fim de analisar como se operam o trabalho com as mídias. Por conseguinte, ela chega a três subcategorias que delimitam e caracterizam esse tipo de ocorrência: a transposição midiática, a combinação das mídias e as referências intermidiáticas.

É importante ressaltar que a própria pesquisadora deixa claro que essas ocorrências não necessariamente aparecem de maneira isolada, mas "uma única configuração midiática 
pode preencher os critérios de dois ou até de todas as três das categorias intermidiáticas apresentadas" (RAJEWSKY, 2012, p. 26). É o que se verifica em Húmus poema contínuo, pois o poema é constituído por diferentes mídias, portanto, uma combinação midiática, ao mesmo tempo em que transpõe textos oriundos da mídia impressa para a digital, isto é, realiza o processo de remediação.

Nesse sentido, no campo das imbricações textuais, entendemos, com Rajewsky, que o poema de Torres estabelece uma "combinação de mídias", pois

A qualidade intermidiática dessa categoria é determinada pela constelação midiática que constitui um determinado produto de mídia, isto é, o resultado ou o próprio processo de combinar, pelo menos, duas mídias convencionalmente distintas ou, mais exatamente, duas formas midiáticas e articulação. (RAJEWSKY, 2012, p. 24)

Na obra hipermidiática de Torres, as linguagens se fundem, formando a constelação midiática acima apontada: o texto de Brandão aparece como fundo de tela, espécie de moldura ao poema; a linguagem sonora presente na trilha musical e na voz que lê; as linguagens de programação XML (para exportação) e Actionscript (animação interativa), as quais proporcionam a execução do texto, que se realiza performaticamente.

Ainda que autônomo, o poema hipermidiático pode também ser visto como uma transposição midiática. Nesse caso, Rajewsky determina que "[sua] formação é baseada num processo de transformação específico da mídia e obrigatoriamente intermidiático" (RAJEWSKY, 2012, p. 24). Ao estabelecer um novo espaço de escrita e leitura, as mídias digitais tanto reconfiguram quanto atualizam a forma como lidamos com o texto, seja como autor ou leitor. Isso remete ao que Bolter e Grusin consideram como característica fundamental das novas mídias digitais e que também está no campo da Intermidialidade, a remediação, ou seja, o fato de uma nova mídia alterar, substituir e/ou redefinir mídias anteriores. Vimos que Helder parte de recortes do texto de Brandão e, a partir do processo de montagem, constrói seu poema. É possível pensar que esse princípio poderia ser refeito/repetido inúmeras vezes e de várias formas, sobretudo, instigados pela "regra" disposta pelo próprio Helder: "liberdades, liberdade". No entanto, as condições de produção do impresso no campo editorial e mercadológico rareiam essa replicação, muito embora uma obra possa ter sucessivas edições. Nesse aspecto, o digital é mais versátil e, para além de favorecer toda uma gama de experimentos, permite que haja uma articulação mais dinâmica com as versões de uma obra, que podem ser armazenadas num repositório.

\section{Rui Torres e seus precursores}

No ensaio Kafka y sus precursosres, o escritor argentino Jorge Luis Borges faz uma instigante reflexão acerca de como as obras do presente modificam nossa relação com as do passado. Enquanto em arte comumente se fala em influência, ou seja, na maneira como artistas contemporâneos bebem em fontes da tradição, do cânone, Borges faz uma proposição que inverte essa lógica, ao considerar que a leitura de um escritor a posteriori modifica nossa relação com um texto anterior, já que lança novas perspectivas sobre ele.

Nesse sentido, embora Rui Torres parta de duas obras precedentes, isso não resulta em uma obra ciberpoética de menor tensão criativa. Trata-se de um grande desafio criar algo novo e ao mesmo tempo lidar com o que Harold Bloom caracterizava como "imensas angústias de débito" (BLOOM, 1991, p. 33). Na verdade, o gesto de (re)escrita de Torres coloca em 
movimento dois autores importantes em tempos distintos do século XX português, fazendo eclodir seu caráter de vanguarda, mas também o reposicionamento do texto de Brandão, ressignificando-o numa perspectiva sincrônica. Como diz Borges a respeito de Kafka em relação a Browning: "O poema Fears and scruples (...) profetiza a obra de Kafka, mas nossa leitura de Kafka afina e desvia sensivelmente nossa leitura do poema. Browning não o lia como agora nós o lemos." (BORGES, 2009, p. 81, grifos nossos, tradução nossa). ${ }^{2}$

De acordo com a lógica borgeana, Torres nos faz perceber como o processo eleito por Helder, na década de 60, na composição de seu Húmus - o da montagem a partir de fragmentos de Brandão - antecipa uma técnica que os meios digitais não só colocam em funcionamento, como a ampliam e potencializam. O poema de Torres indubitavelmente é um texto que se inscreve na contemporaneidade, ao proporcionar uma escrita simultânea ao ato da leitura, em constante atualização, com inúmeras possibilidades de elaboração. Mas, por mais contemporâneo que seja esse processo, ele já estava inscrito na poesia de Helder: o exercício da reescrita, a partir do recorte, da colagem e da montagem. Se Helder, como reconhecem Torres e Ministro, se apropria de uma técnica cinematográfica bastante conhecida, ele não deixa de lançar possibilidades para um tipo de elaboração poética que viria a posteriori, mas que só nos é perceptível porque Torres a colocou em evidência no Húmus - poema contínuo.

Para engendrar o processo de escrita contínua em seu poema, Torres o "alimentou" com as palavras de Brandão. Isso só se torna possível porque o texto de Brandão já apresentava elementos de composição que permitem as diversas permutações que dele partem. Do mesmo modo, a feição ambígua e porosa do texto de Brandão inscreve-se na construção do poema de Rui Torres - maleável, múltiplo, anfibológico, metamorfose de metamorfoses - ou ainda nos vazios e repetições que irão caracterizar o primeiro Húmus que, a bem dizer, não narra, medita. Analisando a obra, os estudiosos afirmam: "é precisamente esta recusa das convenções literárias e a consciência de escrita enquanto algo nunca finalizado que parecem arrancar Raul Brandão às práticas textuais correntes da altura em que escrevia" (MINISTRO; TORRES, 2016, p. 153) e que, ao mesmo tempo, podemos dizer, levam Torres à construção de um poema em (re)escrita contínua e ininterrupta.

Torres, assim, resgata e atualiza o caráter de metamorfose e vanguarda que a obra de Brandão apresentava já no início do século XX, marcada pela "abolição da oposição entre prosa e poesia", por romper com as fronteiras de gêneros e com a escrita tradicional da narrativa e, com quase um século de distância, também as fronteiras temporais. É como se a metáfora do Húmus de 1917 “atrás desta vila há outra vila maior", se transmutasse para a obra em questão: atrás deste texto há outro, e outro maior.

Em artigo que escreve sobre outro poema digital de sua autoria, Amor de Clarice, Torres demonstra que escrever a partir de outra obra/autor implica em exercício não só de criação, mas também de reflexão crítica: "Escrever para dialogar com um texto: admitir a possibilidade de ser a reescrita criativa dos textos que lemos um dos possíveis nódulos da crítica literária" (TORRES, 2003). Assim também Húmus - poema contínuo coloca em movimento esses dois processos: o da criação artística e o da análise crítica - indissociáveis, porque estão na composição da mesma obra e, ao mesmo tempo, complementares, pois a teoria elucida a criação, ao mesmo tempo que a criação faz-nos repensar a teoria.

\footnotetext{
${ }^{2}$ El poema Fears and Scruples de Browning profetiza la obra de Kafka, pero nuestra lectura de Kafka afina y desvía sensiblemente nuestra lectura del poema. Browning no lo leia, como ahora nosotros lo leemos. (BORGES, 2009, p. 81)
} 
Dessa maneira, para Torres, a escrita ou a reescritura digital de uma obra implica o domínio de uma ferramenta e uma perspectiva crítico-criativa. O ciberpoeta "desmonta" Húmus, no plano crítico, pela compreensão dos processos estéticos da apropriação de Helder sobre o texto de Brandão e "recombina" os signos dessas obras num texto terceiro. Isso porque o autor toma para si a técnica estudada sobre o poema de Helder, levando em conta a confissão da apropriação do poeta de Oи о poema contínuo: "Material: palavras, frases, fragmentos, imagens, metáforas do Húmus de Raul Brandão; Regra: liberdades, liberdade."(HELDER, 2004, p. 224). Essa regra única de Helder é um convite ao projeto de Rui, que se orientará pela programação computacional do texto, articulando os elementos aleatórios e combinatórios para a sua releitura do projeto de Helder. O projeto é em si essa percepção de abertura da obra, naquele sentido que Umberto Eco dizia sobre a "obra aberta": aquela que encoraja a consciência de liberdade do leitor/performer; daquela obra proposta como programa produtivo, isto é, que promove a maior abertura possível (ECO, 1968, p. 43).

Torres \& Ministro ressaltam, em relação ao trabalho de Helder, o processo de montagem sob o qual o poema é elaborado: "A montagem é, portanto, o processo principal pelo qual o poema de Helder estabelece e actualiza a leitura do texto de Brandão. Montagem pela ligação das partes num todo, com autonomia própria” (MINISTRO; TORRES, 2016, p. 158). Os críticos lembram-nos que a montagem é um processo cinematográfico e retomam a teoria de Eisenstein, o qual defendia a ideia de que dois pedaços de filmes justapostos resultariam num novo conceito, num novo sentido. Eisenstein estendia o princípio da montagem para além do cinema: "Esta [a montagem] não é, de modo algum, uma característica peculiar do cinema, mas um fenômeno encontrado sempre que lidamos com a justaposição de dois fatos, dois fenômenos, dois objetos" (EISENSTEIN, 2002, p. 14). Daí, então, o trabalho de Helder apresentar-se como um poema-montagem (subtítulo que se encontrava na primeira edição da obra), feito de "pedaços" da obra de Brandão e justapostos em uma nova dinâmica textual. Vejamos uma página escolhida ao acaso para revelar o processo de decupagem entre os textos de Helder e Brandão:

Figura 4 - Página 46 do livro Herberto Helder, leitor de Raul Brandão

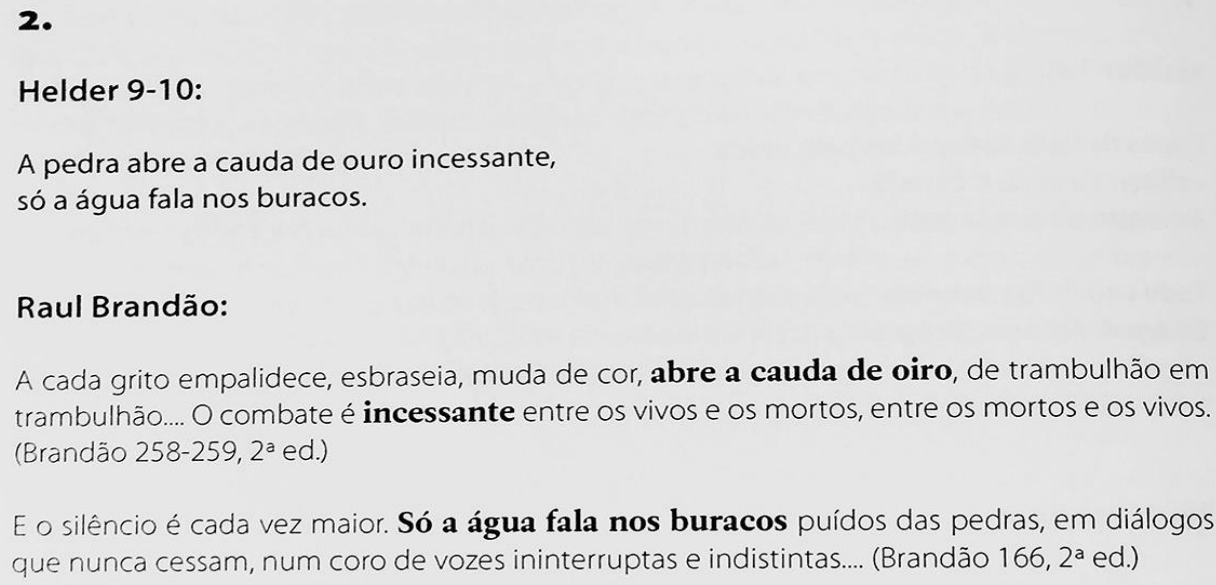

Fonte: TORRES, Rui. Herberto Helder, leitor de Raul Brandão: uma leitura de "Húmus", poema montagem. Porto: Edições Universidade Fernando Pessoa, 2010. p. 46.

Nessa página, observamos que o texto de Helder, assim como será o de Torres, absorve o rico e diversificado léxico de Brandão, recortando, deslocando, reordenando a prosa em prol 
do poema. Se o leitor se depara com o texto de Helder em Poesia toda (Assírio \& Alvim, 1996) ou em edições subsequentes, como em Ou o poema contínuo (Assírio \& Alvim, 2004), encontra um poema autônomo, fragmentário, numa dicção que recupera temas e relações presentes na obra de Helder, como observa essa leitura instigante de Isabela Leal, que vê no poema a mesma busca por um idioma singular e um certo apagamento do enunciador, o que promove tensões no poema:

\begin{abstract}
Cumpre observar que o domínio dos mortos é aquele da linguagem que é legada a todo e qualquer indivíduo por ocasião de seu nascimento, sendo a emergência da subjetividade um acontecimento desta, ainda que o sujeito, ao escrever, isto é, ao criar a sua dicção própria, procure negá-la, como se fosse possível estar fora dela. Essa duas dimensões da relação entre sujeito e linguagem - o legado dos mortos aos vivos e a necessidade de criar os mortos a partir dos vivos, através de uma tentativa de negação - estão presentes em Húmus (LEAL, 2008, p. 128).
\end{abstract}

Noutras palavras, a apropriação constitui um gesto radical, pois o gesto antropofágico de Helder torna o texto de Brandão uma expressão da sua diç̧ão; portanto, modifica profundamente a obra do autor decadentista português, porque a desloca. Entre a publicação de Húmus, de Brandão, e o de Herberto Helder passaram-se quase 50 anos e quase outros tantos separam o texto de Herberto e a obra hipermidiática. Mas a esta obra Torres imprimiu também o sentido do working progress presente nas edições de Helder, metaforizado pelo "poema contínuo". Helder transformou esses fragmentos num poema longo e que se mantém na continuidade do automatismo eletrônico da versão em hipermídia. Assim, quando na Web ou no CD-ROM, um interator/leitor escolhe um fragmento ou estrofe do poema, uma nova combinação de palavras se mostra como (re)escrita do texto. Como dissemos, o vocabulário deriva da obra de Brandão, como antes derivou o poema de Helder. Agora ambos estão em confronto e daí surge uma outra poética para um horizonte aberto. Se considerarmos que o poeta de Servidões é um "tradutor da tradição", como assim o admite o próprio Torres a partir da retomada que Helder faz de Brandão, destacando "mais do que a 'sugestão' de um texto: antes a sua transformação, accionando a sua força latente, ressuscitando-o." (MINISTRO; TORRES, 2016, p. 152), o ciberpoeta exerce também essa função, pois (re)convoca Brandão e realiza uma releitura de Helder o qual, no contexto do poema digital, já é também tradição.

É nesse sentido que colocamos a obra de Torres em relação a Helder e Brandão, já que, ao retomá-las e inserindo-lhes novas feições estilísticas, Húmus poema contínuo provoca redescoberta, recontextualização e ressignificações aos autores a que referencia. Como não há propriamente novidades no campo das culturas, acreditamos que Torres mais renova que inova em relação aos autores que o antecederam. No entanto, nossa percepção em relação a elementos fundamentais das poéticas de Helder e Brandão - hibridismo de linguagem, quebra das fronteiras de gênero, revisão da tradição, vanguardismo - é, certamente, modificada por Húmus, poema contínuo. Assim que, como afirma Borges, "cada escritor crea a sus precursores".

\title{
Húmus, uma escrita palimpséstica ou de "segundo grau"
}

Conforme enunciamos na introdução deste texto, Húmus, tanto na versão escrita por Herberto Helder ou quanto pela forma de "poema-montagem" na obra hipermidiática de Rui Torres, pode ser vista como uma escrita palimpséstica, conforme conceituação de Gerárd Genette. Em sua obra Palimpsestos: La literatura en segundo grado (1989), o teórico trata dos processos de "transposição" quando discorre sobre a hipertextualidade no campo textual do 
impresso. Para Genette, o hipertexto seria o texto construído a partir de uma obra anterior denominada hipotexto -, da qual o segundo emerge, não como texto crítico/analítico, mas como uma nova obra. Se na transposição midiática o foco se encontra na passagem para uma nova mídia no campo emergente da cultura digital e a forma como os recursos dos novos meios serão explorados, na transposição genettiana enfatiza-se as operações transformadoras do hipotexto, que podem ser de ordem diversa (de gênero, estilo, tema, etc.). De qualquer forma, estão imbricadas em ambas a ideia de (re)criação, (re)escrita, reelaboração.

Genette demonstra que o hipertexto comporta uma ambiguidade, já que tanto pode ser considerado em si mesmo, daí a ideia de que se configure como uma obra autônoma, como pode ser lido em relação aos textos com os quais dialoga. Nesse sentido, o crítico defende que o hipertexto sempre ganha quando nele se reconhece as relações intertextuais e acrescenta que, conforme se percebe, os próprios artistas, de alguma forma, dão a conhecer a relação dialógica que suas obras apresentam (GENETTE, 1989, p. 494).

A partir dessas considerações, Genette emprega a metáfora da escrita palimpséstica uma obra que se inscreve sobre outra sem, contudo, apagar completamente os traços da escrita anterior. Dessa forma, vimos que Helder borra a escrita de Brandão, suprimindo, recortando, reorganizando, no entanto, não só por preservar o mesmo título, mas por usar alguns recursos estilísticos, por manter o tom da obra, entre outras recorrências ao primeiro Húmus, as marcas textuais de Brandão são mantidas no poema de Helder.

Torres, por sua vez, exponencia esse processo ao colocar, sob sua escrita, os traços dos dois escritores portugueses referenciados. De Helder, se reconhece o processo; de Brandão, as palavras; apagamento, mas não desaparecimento; reconhecimento de marcas, rastros, vestígios de um texto anterior, ou nos dizeres de Genette: "representar-se mediante a antiga imagem do palimpsesto, na qual se vê, sobre o mesmo pergaminho, como um texto se sobrepõe a outro sem ocultá-lo de tudo, mas que se deixa ver por transparência"3 (GENETTE, 1989, p. 495, tradução nossa). Essa transparência é, de certa forma, aludida nas páginas eletrônicas em que transcorre a hipermídia Húmus, as quais entremostram os rastros do texto de Raul Brandão por trás do texto de Herberto Helder e da própria animação automática que a constituem, como na imagem:

\footnotetext{
3 “(...) representarse mediante la vieja imagen del palimpsesto, en la que se ve, sobre el mismo pergamino, cómo un texto se superpone a otro al que no oculta del todo sino que lo deja ver por transparência" (GENETTE, 1989, p. 495).
} 
Figura 5 - Página de Húmus na Web

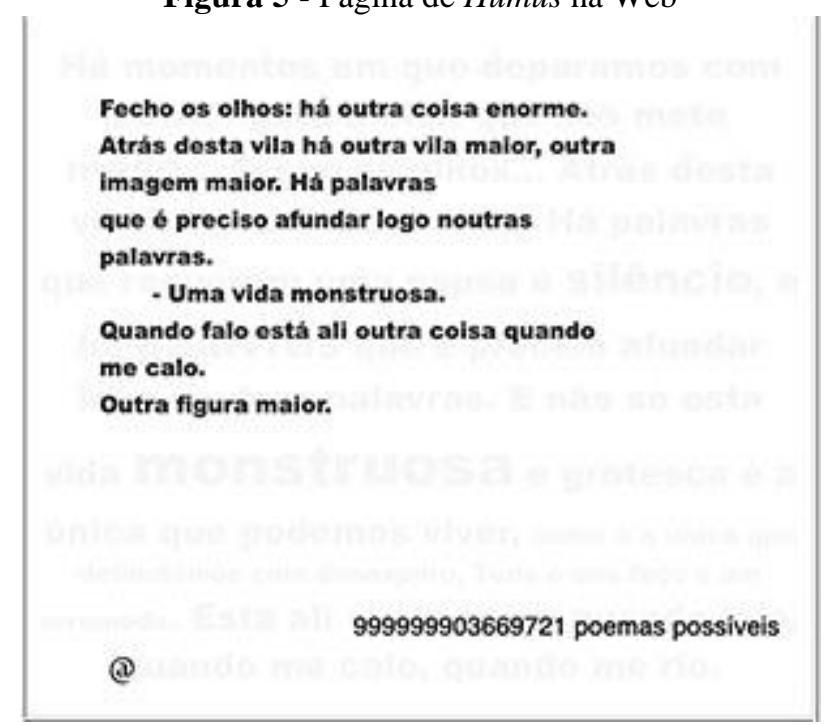

Fonte: http://telepoesis.net/poemario/

Entendemos que não se trata de um jogo gratuito ou mesmo ornamental, uma vez que o palimpsesto pode ser visto, de certo modo, como uma "vingança" contra a rasura da escrita. Como se deu na cultura midiática do pergaminho e do papiro, repete-se similarmente na cultura digital: o velho texto reinscreve-se como um fantasma a reivindicar o seu lugar na memória cultural. Por fim, para relembrar o Barthes, de O rumor da língua (BARTHES, 2004), o rumorejar é a forma utópica para evitar o engasgamento do motor, mantendo-se abertos os sentidos. Húmus, poema contínuo coloca-se nesse nível de inscrição, como escrita algorítmica potencial capaz de reimaginar a literatura e a própria poesia no cenário das tecnologias digitais. Nesse caso, transpor a arte entre mídias ou remediar os meios é em si uma nova forma de imaginação da arte e da literatura.

\section{Referências}

BARTHES, R. O rumor da língua. Tradução de Mário Laranjeira. 2. ed. São Paulo: Martins Fontes, 2004.

BLOOM, H. A angústia da influência: uma teoria da poesia. Tradução e apresentação de Arthur Nestrovski. Rio de Janeiro: Imago, 1991.

BOLTER, J. D. Wrtiting Space: Computers, Hypertext, and the Remediation of Print. New Jersey, USA: Lawrence Erlbaum Associates, Inc., 2001.

BOLTER, J. D.; GRUZIN, R. Remediation: Understanding New Media. Cambrigde, Massachussets: MIT Press, 2000.

BORGES, J. L. Kafka y sus precursores. In: BORGES, J. L. Obras completas II: Edición Crítica. Anotada por Rolando Costa Picazo e Irmã Zangara. Buenos Aires: Emecé, 2009. p. 80-81. 
BRANDÃO, R. Húmus. São Paulo: Carambaia, 2017.

ECO, U. Obra aberta. Tradução de Giovanni Cutolo. São Paulo: Perspectiva, 1968.

EISENSTEIN, S. O sentido do filme. Tradução de Teresa Ottoni. Rio de Janeiro: Jorge Zahar, 2002.

GENETTE, G. Palimpsestos: la literatura en segundo grado. Traducción de Celia Fernández Prieto. Madrid: Altea, Taurus, Alfaguara, 1989.

HEIDEGGER, M. Sobre a mão e a máquina de escrever (1942-1943). In: KLITTLER, Friedrich A. Gramofone, filme, typewriter. Tradução de Daniel Martineschen e Guilherme G. Flores. Belo Horizonte: Editora UFMG, 2019. p. 276-278.

HELDER, H. Húmus. In: HELDER, H. Ofício Cantante - poesia completa. Lisboa: Assírio \& Alvim, 2009. p. 278-292.

KIRCHOF, E. R. Como ler os textos literários na era da cultura digital? Estudos de literatura brasileira contemporânea, n. 47, p. 203-228, 2016. Disponível em: https://periodicos.unb.br/index.php/estudos/article/view/10098/8924. Acesso em 27 jul. 2020.

LEAL, I. No reino das mães: notas sobre a poética de Herberto Helder. Cadernos da UFF Dossiê: Literatura, língua e identidade, n. 34, p. 127-138, 2008.

MINISTRO, B.; TORRES, R. Húmus: Colagem; Montagem; Recombinação. Elyra Revista da rede internacional Lyra Compoetics, n. 7, 2016, p. 151-76. Disponível em: https://elyra.org/index.php/elyra/article/view/119/115. Acesso em 29 set. 2019.

RAJEWSKY, I. O. Intermidialidade, Intertextualidade e "Remediação" - uma perspectiva literária sobre a intermidialidade. Tradução de Thaïs F. N. Diniz e Eliana L. L. Reis. In:

DINIZ, T. F. N. (org.). Intermidialidade e Estudos Interartes: desafios da arte contemporânea. Belo Horizonte: Editora UFMG, 2012. p. 15-45.

TORRES, R. Herberto Helder, leitor de Raul Brandão: uma leitura de "Húmus", poema montagem. Porto: Edições Universidade Fernando Pessoa, 2010. (Inclui CD-ROM).

TORRES, R. Húmus poema contínuo. Disponível em:

http://telepoesis.net/Húmus/humus_index.html. Acesso em 29 set. 2019.

TORRES, R. Ler Clarice Lispector, re-escrevendo Amor. Disponível em: http://telepoesis.net/papers/clamor.pdf. Acesso em 02 jan. 2012.

Recebido em: 31 de julho de 2020 Aceito em: 25 de novembro de 2020

Publicado em dezembro de 2020 